\title{
EFEKTIFITAS MODEL PEMBELAJARAN APTITUDE TREATMENT INTERACTION (ATI) DALAM MENINGKATKAN AKTIVITAS BELAJAR SISWA MTsN MOJOROTO KOTA KEDIRI
}

\author{
Djoni Hartono \\ MTs Negeri Mojoroto Kota Kediri \\ e-mail: djonihartono436@gmail.com
}

\begin{abstract}
The different character of student makes the teacher applies exact learning model in order to all of student can follow the learning well. Learning model which is taked im this study is aptitude treatment interaction (ATI) as experiment to increase student learning activity at learning IPS for matery geographic condition of asean countries in VII-C MTsN Mojoroto Kota Kediri. This study is devided to three cycles, the results of it are: (1) there is increase of student activity but the domination of teacher is still much (2) learning activity which involve student activity is increase such as small group discussion, etc (3) domination teacher activities are guidance and monitoring student. Therefore ATI learning model could make student learning activity increase, so that student learning achievment follows it.
\end{abstract}

Karakteristik siswa yang beragam membuat guru perlu menerapkan model pembelajaran yang tepat agar seluruh siswa dapat mengikuti pembelajaran dengan baik. Model pembelajaran yang diterapkan dalam penelitian ini adalah Aptitude Treatment Interaction (ATI) sebagai uji coba untuk meningkatkan aktivitas belajar siswa pada mata pelajaran IPS materi kondisi geografis negara-negara asean di kelas VIII-C MTsN Mojoroto Kota Kediri. Penelitian ini terbagi menjadi tiga siklus dengan hasil sebagai berikut: (1) terdapat peningkatan keaktifan siswa tetapi masih banyak dominasi guru, (2) kegiatan belajar yang melibatkan keaktifan siswa mengalami peningkatan seperti diskusi kelompok kecil, dan sebagainya, (3) aktifitas guru yang paling dominan adalah membimbing dan mengamati siswa. 
Dengan demikian model pembelajaran ATI telah mampu membuat aktifitas belajar siswa meningkat sehingga prestasi belajar siswa pun ikut meningkat.

Keywords: Aptitude Treatment Interaction, Learning Activity.

\section{Pendahuluan}

Dalam satu kelas terdapat sekelompok siswa dengan keragaman individu yang unik. Artinya, setiap individu memiliki perbedaan antara satu dengan yang lain. Begitu pula dalam hal belajar, masing-masing siswa memiliki kelebihan dan kekurangan dalam menyerap pelajaran yang disampaikan. Di samping itu, perbedaan individu juga merupakan salah satu ciri pengajaran modern yang menganggap manusia sebagai makhluk individual yang tidak bisa diperlakukan dengan cara yang sama karena perbedaan individu itu terdiri dari berbagai macam hal dan guru harus mengetahui siapa yang diajarnya, khususnya terkait dengan kesiapan dan kematangan siswa dalam mengikuti proses pembelajaran. ${ }^{1}$ Sehingga diperlukan pendekatan secara individual dalam pelaksanaan pembelajaran di kelas. Perbedaan individual siswa tersebut memberikan wawasan kepada guru bahwa pemilihan model pembelajaran harus memperhatikan perbedaan individual siswa.

Dengan kata lain, guru harus melakukan pendekatan individual dalam mengajarnya agar pelaksanaan pembelajaran dapat berlangsung lebih baik.Penentuan pendekatan pembelajaran tersebut pada tahap selanjutnya berdampak pada

\footnotetext{
${ }^{1}$ Daryanto, Evaluasi Pendidikan (Jakarta: Rineka Cipta, 2012), 199-202.
} 
pemilihan model pembelajaran yang sesuai, yaitu model pembelajaran yang mampu memenuhi perbedaan individual siswa agar potensi siswa dapat berkembang secara maksimal. Hal ini sejalan dengan pendapat Djamarah yang menjelaskan bahwa, sebagai manusia yang berpotensi, maka dalam diri setiap siswa ada daya yang dapat tumbuh dan berkembang di sepanjang usianya. Potensi siswa sebagai daya yang tersedia, sedangkan pendidikan sebagai alat ampuh yang seharusnya mampu mengembangkan daya itu. ${ }^{2}$ Selain itu, keberhasilan guru dalam membelajarkan siswa tercermin dalam keberhasilannya mengantarkan siswa memperoleh prestasi belajar yang baik atau setidaknya mencapai kriteria kelulusan minimal pada suatu mata pelajaran tertentu.

Perbedaan individual merupakan salah satu prinsip terciptanya interaksi edukatif yang efektif antara guru dengan siswa. Perbedaan tersebut harus disadari guru agar guru tidak terkejut melihat tingkah laku dan perbuatan maupun sikap siswanya yang beragam antara satu dengan lainnya. Menurut Djamarah, aspek perbedaan individual peserta didik dapat digolongkan ke dalam beberapa aspek, antara lain aspek biologis, intelektual dan psikologis. Lebih lanjut, Djamarah menegaskan bahwa kegagalan guru dalam menuntaskan penguasaan siswa atas bahan pelajaran yang diberikan, salah

\footnotetext{
${ }^{2}$ Syaiful Bahri Djamarah, Guru dan Anak Didik dalam Interaksi Edukatif (Jakarta: Rineka Cipta, 2005), 52.
} 
satunya disebabkan karena guru gagal memahami perbedaan individual siswa. ${ }^{3}$

Banyak faktor lain yang mempengaruhi keberhasilan pelaksanaan pembelajaran di antaranya, tujuan sebagai pedoman sekaligus sasaran yang akan dicapai dalam pembelajaran, guru sebagai pendidik yang mentransfer dan mentransformasikan sejumlah ilmu pengetahuan kepada siswa di sekolah, anak didik, kegiatan pengajaran, bahan dan alat evaluasi, serta suasana evaluasi. ${ }^{4}$ Faktor-faktor tersebut tidak selamanya memberikan pengaruh positif terhadap prestasi belajar maupun keaktifan siswa dalam mengikuti pembelajaran di kelas sehingga perlu dikemas melalui kerangka konseptual yang dapat digunakan sebagai pijakan dalam melaksanakan rangkaian kegiatan pembelajaran, yaitu model pembelajaran. Model pembelajaran pada dasarnya merupakan bentuk pembelajaran yang tergambar dari awal sampai akhir yang disajikan secara khas oleh guru. Dengan kata lain, model pembelajaran merupakan bungkus atau bingkai dari penerapan suatu pendekatan, metode, dan teknik pembelajaran. $^{5}$

Dalam konteks penelitian ini, peneliti berupaya menerapkan model pembelajaran aptitude treatment interaction

\footnotetext{
${ }^{3}$ Djamarah, Guru dan Anak Didik, 69.

4 Syaiful Bahri Djamarah dan Aswan Zein, Strategi Belajar Mengajar (Jakarta: Rineka Cipta, 2013), 109-119.

5 Akhmad Sudrajat, "Pengertian Pendekatan, Strategi, Metode, Teknik, Taktik dan Model Pembelajaran", https://akhmadsudrajat.wordpress.com/2008/09/12/pendekatan-strategimetode-teknik-dan-model-pembelajaran/
} 
(ATI) pada mata pelajaran Ilmu Pengetahuan Sosial (IPS) untuk meningkatkan prestasi belajar dan keaktifan siswa dalam proses pelaksanaan pembelajaran di kelas karena model ini dianggap sesuai untuk mengakomodasi berbagai perbedaan individual siswa baik dalam aspek inteletual maupun psikologis. Adapun rumusan masalah dalam penelitian ini adalah: bagaimana penerapan model pembelajaran aptitude treatment interaction (ATI) dalam meningkatkan keaktifan belajar siswa pada mata pelajaran IPS materi kondisi geografis negara-negara asean di kelas VIII-C MTsN Mojoroto Kota Kediri.

Secara umum, penelitian ini diharapkan mampu meningkatkan aktivitas belajar siswa, khususnya pada mata pelajaran IPS serta dapat mendorong kreatifitas dan inovasi para guru untuk mengujicobakan berbagai model, strategi dan metode pembelajaran sehingga pelaksanaan pembelajaran menjadi lebih menarik dan mampu memotivasi siswa untuk mengikuti pembelajaran secara optimal sehingga hasil belajar siswa meningkat sesuai dengan potensinya masing-masing.

\section{Perbedaan Individual Siswa}

Secara kodrati, manusia memiliki potensi dasar yang secara esensial membedakan manusia dengan hewan, yaitu pikiran, perasaan, dan kehendak. Sekalipun demikian, potensi dasar yang dimiliki tidak sama bagi masing-masing manusia. ${ }^{6}$

\footnotetext{
${ }^{6}$ Sunarto dan Agung Hartono, Perkembangan Peserta Didik (Jakarta: Rineka Cipta, 2008), 10.
} 
Perbedaan potensi dasar itu merupakan bentuk perbedaan individual yang harus diapresiasi karena ia merupakan ekspresi keunikan kepribadian siswa. Pendidikan diharapkan diharapkan mampu mengokohkan identitas individu mereka dan mendorong agar identitas tersebut dapat dipertahankan di tengah kebudayaan dan segala perangkatnya. $^{7}$ Dalam proses pendidikan, peserta didik merupakan sumber daya utama dan terpenting. Peserta didik bisa belajar tanpa guru. Namun sebaliknya, guru tidak bisa mengajar tanpa peserta didik. Karenanya kehadiran peserta didik menjadi keniscayaan dalam proses pendidikan formal atau pendidikan yang dilambangkan dengan menuntut interaksi antara pendidik dan peserta didik. ${ }^{8}$

Siswa juga merupakan salah satu komponen sentral dalam proses belajar mengajar. Dalam proses belajar mengajar yang pertama kali harus diperhatikan adalah siswa, baru setelah itu menentukan komponen-komponen pembelajaran lainnya sehingga semua komponen tersebut seharusnya disesuaikan dengan karakteristik siswa, karena siswa adalah subjek belajar. Di samping itu, belajar yang lebih efektif hanya mungkin jika siswa turut aktif dalam merumuskan serta memecahkan berbagai masalah. Dengan demikian, esensi guru mengajar adalah

7 Bruce Joyce, Marsha Weil, dan Emily Calhoun, Models of Teaching: Model-model Pengajaran. terj. Achmad Fawaid dan Ateilla Mirza (Yogyakarta: Pustaka Pelajar, 2011), 449.

8 Sudarwan Danim, Perkembangan Peserta Didik, ( Bandung: Alfabeta, 2010), 1 . 
menyediakan situasi dan kondisi belajar yang kondusif agar masing-masing siswa dapat belajar secara optimal. ${ }^{9}$

Secara umum, Djamarah menjelaskan bahwa perbedaan individual siswa atau peserta didika dapat digolongkan ke dalam tiga aspek, yaitu perbedaan biologis, intelektual, dan psikologis. Perbedaan biologis adalah cirri-ciri individu yang dibawa sejak lahir seperti warna kulit, bentuk tubuh, warna rambut, mata, kesehatan, penyakit, dan sebagainya. Kedua, perbedaan intelektual yaitu kemampuan untuk memahami dan menyesuaikan diri dengan situasi baru secara cepat dan efektif. Dalam rangkan mengetahui tingkat intelegensi seseorang, dikembangkanlah instrument yang disebut tes intelegensi dan gambaran hasil tes tersebut kemudian dikenal dengan istilah intelligence quotient (IQ). Ketiga, perbedaan psikologis. Secara psikologis, setiap peserta didik atau siswa mempunyai perbedaan karakteristik masing-masing, misalnya ada yang murah senyum, berjiwa sosial, pemurung, periang, dan sebagainya yang kesemuanya itu banyak dipengaruhi oleh pembawaan dan lingkungan. Dalam pengajaran, aspek psikologis yang banyak menjadi persoalan adalah masalah minat dan perhatian peserta didik terhadap bahan pelajaran yang diberikan oleh guru. Perbedaan-perbedaan tersebut mesti dipahami dengan baik oleh guru agar dapat dimanfaatkan untuk melakukan pendekatan yang sesuai terhadap peserta didik

9 Sardiman A.M, Interaksi dan Motivasi Belajar Mengajar (Jakarta: RajaGrafindo Persada, 2014), 111-119. 
sekaligus strategi ampuh untuk mendukung keberhasilan interaksi edukatif dalam proses pembelajaran. ${ }^{10}$

\section{Model Pembelajaran Aptitude Treatment Interaction (ATI)}

Joyce dan Weill dalam Huda mendeskripiskan model pengajaran sebagai rencana atau pola yang dapat digunakan untuk membentuk kurikulum, mendesain materi pelajaran, dan memandu proses pembelajaran di kelas dengan setting yang berbeda. Sebagian model tersebut ada yang berpusat pada penyampaian guru dan ada yang fokus pada respons siswa. Akan tetapi semua model pengajaran atau pembelajaran tersebut mengarah pada bagaimana membantu siswa belajar secara optimal. $^{11}$

Secara lebih spesifik, Nurdin dalam Dongoran menjelaskan bahwa model pembelajaran Aptitude Treatment Interaction (ATI) bertujuan untuk menciptakan dan mengembangkan suatu model pembelajaran yang betul-betul peduli dan memperhatikan keterkaitan antara kemampuan (aptitude) seseorang dengan pengalaman belajar. Untuk mencapai tujuan tersebut, model ini berupaya menemukan dan memilih sejumlah perlakuan (treatmet) yang tepat sesuai dengan

\footnotetext{
${ }^{10}$ Djamarah, Guru dan Anak Didik, 55-61.

11 Miftahul Huda, Model-model Pengajaran dan Pembelajaran: Isu-isu Metodis dan Pragmatis (Yogyakarta: Pustaka Pelajar, 2014), 73-74.
} 
perbedaan kemampuan siswa. ${ }^{12}$ Dengan kata lain, model pembelajaran ATI adalah suatu model yang mencari kesesuaian antara perlakuan yang diberikan atau dikembangkan dengan perbedaan kemampuan masing-masing siswa untuk memaksimalkan potensi yang ada dalam diri siswa sehingga siswa mampu memperoleh hasil belajar yang optimal. Secara sederhana, model ATI dapat diartikan sebagai model pembelajaran yang berusaha mencari kesesuaian antara perlakuan yang diberikan guru dengan kemampuan belajar siswa yang berbeda sehingga interaksi edukatif dapat berlangsung lebih maksimal.

Pelaksanaan model ini terdiri dari empat tahapan. Pertama, treatment awal. Perlakuan awal terhadap siswa dilakukan dengan memberikan aptitude testing untuk menentukan dan menetapkan klasifikasi kelompok siswa berdasarkan tingkat kemampuannya. Kedua, pengelompokkan siswa. Pengelompokkan ini merupakan tindak lanjut dari hasil aptitude testing yang menjadi beberapa kelompok siswa (tinggi/cepat, sedang, rendah/lambat. Ketiga, memberikan perlakuan (treatment). Misalnya, siswa yang berkemampuan tinggi diberi perlakuan berupa belajar mandiri melalui modul, siswa yang sedang diberikan pembelajaran regular, dan siswa yang berkemampuan rendah diberikan perlakuan berupa pembelajaran

12 Zulkipli Dongoran, "Efek Model Pembelajaran ATI (Aptitude Treatment Interaction) terhadap Aktivitas dan Generik Sains Fisika Siswa", Jurnal Pendidikan Fisika, Vol. 3 No. 2 (2014), 41-42. 
regular dan tutorial. Keempat, achievment test, yaitu penilaian prestasi belajar setelah siswa diberikan perlakuan berdasarkan klasifikasi kelompok yang telah dibentuk berdasarkan aptitude testing. ${ }^{13}$ Pemilihan model ATI dalam penelitian ini dikarenakan model ini mampu memaksimalkan perbedaan individual siswa sehingga para siswa dapat lebih aktif dan bersemangat dalam mengikuti kegiatan pembelajaran di kelas.

\section{Metode Penelitian}

Penelitian ini menggunakan jenis penelitian tindakan kelas yang berlangsung melalui empat tahapan, antara lain tahap perencanaan, pelaksanaan, pengamatan dan refleksi. Berikut ini penjelasan dari tahap-tahap tersebut: ${ }^{14}$

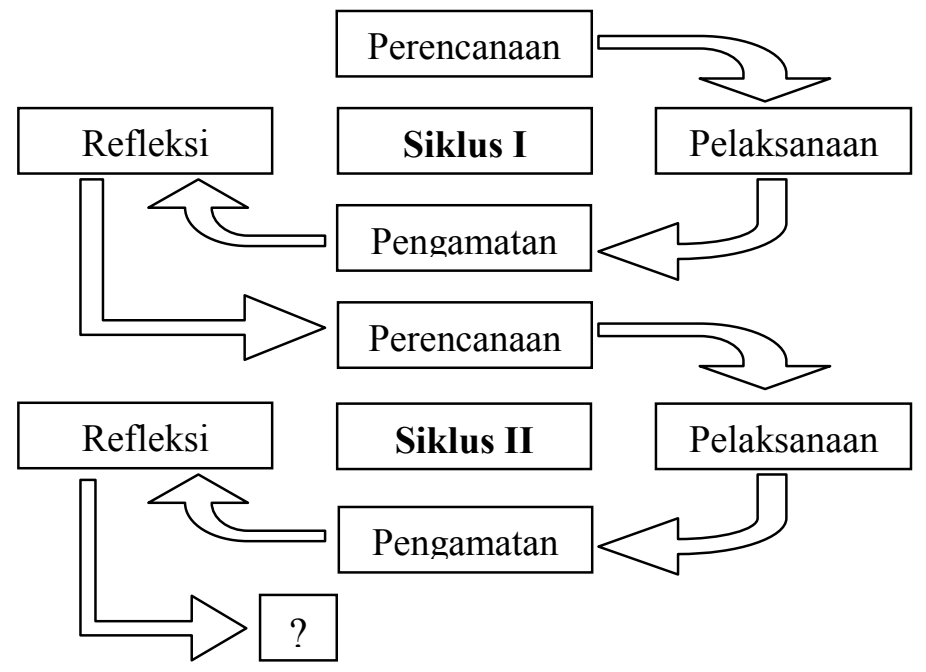

13 Warta Madani, "Konsep Pembelajaran ATI (Aptitude Treatment Interaction)", dalam http://jenteranews.blogspot.com/2013/05/konseppembelajaran-ati-aptitude.html

${ }^{14}$ Suharsimi Arikunto, Penelitian Tindakan Kelas (Jakarta: Bumi Aksara, 2010), 16. 
Berdasarkan gambar di atas, maka tahapan dalam penelitian ini dimulai dari tahap perencanaan. Pada tahap perencanaan, peneliti mempersiapkan perangkat pembelajaran dengan menggunakan model aptitude treatment interaction yang terdiri dari penyusunan rencana pelaksanaan pembelajaran, soal tes formatif, lembar observasi, dan alat-alat pendukung lainnya yang dapat menunjang pelaksanaan pembelajaran. Pada tahap pelaksanaan, peneliti menerapkan model pembelajaran aptitude treatment interaction sebagaimana tertulis dalam rencana pelaksanaan pembelajaran. Pada tahap pengamatan, peneliti melakukan pengamatan secara seksama terkait hal-hal yang terjadi selama proses pelaksanaan pembelajaran di kelas berlangsung. Pada tahap akhir (refleksi), peneliti menganalisis hasil observasi pada siklus pertama sebagai bahan evaluasi untuk menentukan apakah siklus pertama dapat dilanjutkan atau hanya cukup dengan satu siklus.

\section{Siklus I}

Tahap Perencanaan

Pada tahap ini peneliti mempersiapkan perangkat pembelajaran yang terdiri dari rencana pelajaran 1, soal tes formatif 1 dan alat-alat pengajaran yang mendukung. Tahap Pelaksanaan

Pelaksanaan kegiatan belajar mengajar untuk siklus I dilaksanakan pada minggu kedua tanggal 12 Januari 2016 dengan jumlah siswa 46 siswa, dalam hal ini peneliti bertindak sebagai guru. Adapun proses belajar mengajar mengacu pada 
Djoni Hartono

rencana pelajaran yang telah dipersiapkan. Pengamatan (observasi) dilaksanakan bersamaan dengan pelaksaaan pembelajaran.

Pada akhir proses pelaksanaan pembelajaran, siswa diberi tes formatif I dengan tujuan untuk mengetahui tingkat keberhasilan siswa dalam proses belajar mengajar yang telah dilakukan. Adapun data hasil penelitian pada siklus I adalah sebagai berikut:

Tabel 1: Pengelolaan Pembelajaran Pada Siklus 1

\begin{tabular}{|c|c|c|c|c|}
\hline \multirow{2}{*}{ No. } & \multirow{2}{*}{ Aspek yang Diamati } & \multicolumn{2}{|c|}{ Penilaian } & \multirow{2}{*}{$\begin{array}{c}\text { Rata- } \\
\text { rata }\end{array}$} \\
\hline & & P1 & $\mathrm{P} 2$ & \\
\hline \multirow{14}{*}{ I } & Pengamatan KBM & & & \\
\hline & Pendahuluan & & & \\
\hline & 1. Memotivasi Siswa & 2 & 2 & 2 \\
\hline & $\begin{array}{l}\text { 2. Menyampaikan tujuan } \\
\text { pembelajaran }\end{array}$ & 2 & 2 & 2 \\
\hline & $\begin{array}{l}\text { 3. Menghubungkan dengan } \\
\text { pelajaran sebelumnya }\end{array}$ & 2 & 2 & 2 \\
\hline & $\begin{array}{l}\text { 4. Mengatur siswa dalam } \\
\text { kelompok-kelompok } \\
\text { belajar }\end{array}$ & 2 & 2 & 2 \\
\hline & Kegiatan Inti & & & \\
\hline & $\begin{array}{l}\text { 1. Mempresentasikan } \\
\text { langkah-langkah metode } \\
\text { pembelajaran kooperatif }\end{array}$ & 3 & 3 & 3 \\
\hline & $\begin{array}{l}\text { 2. Membimbing } \\
\text { melakukan kegiatan }\end{array}$ & 3 & 3 & 3 \\
\hline & $\begin{array}{l}\text { 3. Melatih keterampilan } \\
\text { kooperatif }\end{array}$ & 3 & 3 & 3 \\
\hline & $\begin{array}{l}\text { 4. Mengawasi } \\
\text { kelompok secara bergiliap }\end{array}$ & 3 & 3 & 3 \\
\hline & $\begin{array}{l}\text { 5. Memberikan bantuan } \\
\text { kepada kelompok yang } \\
\text { mengalami kesulitan }\end{array}$ & 3 & 3 & 3 \\
\hline & Penutup & & & \\
\hline & 1. Membimbing & 3 & 3 & 3 \\
\hline
\end{tabular}


Efektifitas Model Pembelajaran

\begin{tabular}{|c|c|c|c|c|}
\hline & membuat rangkuman & & & \\
\cline { 2 - 5 } & 2. Memberikan evaluasi & 3 & 3 & 3 \\
\hline II & Pengelolaan Waktu & 2 & 2 & 2 \\
\hline \multirow{3}{*}{ III } & Antusiasme Kelas & & & \\
\cline { 2 - 5 } & 1. Siswa & 2 & 2 & 2 \\
\cline { 2 - 5 } & 2. Guru Jumlah & 3 & 3 & 3 \\
\hline & \multicolumn{2}{|c|}{36} & 36 & 36 \\
\hline
\end{tabular}

Keterangan: Nilai : Kriteria

1) : Tidak Baik

2) : Kurang Baik

3) : Cukup Baik

4) : Baik

Berdasarkan tabel di atas aspek-aspek yang mendapatkan kriteria kurang baik adalah memotivasi siswa, menyampaikan tujuan pembelajran, pengelolaan waktu, dan siswa antusias. Keempat aspek yang mendapat nilai kurang baik di atas, merupakan suatu kelemahan yang terjadi pada Tes I dan akan dijadikan bahan kajian untuk refleksi dan revisi yang akan dilakukan pada tes II. Hasil observasi berikutnya adalah aktivitas guru dan siswa seperti pada tabel berikut:

Tabel 2: Aktivitas Guru dan Siswa Pada Siklus 1

\begin{tabular}{|l|l|c|}
\hline No. & \multicolumn{1}{|c|}{ Aktivitas Guru yang Diamati } & Persentase \\
\hline 1 & Memotivasi siswa & 5,0 \\
\hline 2 & Menyampaikan tujuan & 8,3 \\
\hline 3 & Mengkaitkan dengan pelajaran sebelumnya & 8,3 \\
\hline 4 & Menyampaikan materi/ langkah-langkah & 6,7 \\
\hline 5 & Menjelaskan materi yang sulit & 13,3 \\
\hline 6 & $\begin{array}{l}\text { Membimbing dan mengamati siswa dalam } \\
\text { menemukan konsep }\end{array}$ & 21,7 \\
\hline 7 & $\begin{array}{l}\text { Meminta siswa menyajikan dan } \\
\text { mendiskusikan hasil kegiatan }\end{array}$ & 10,0 \\
\hline 8 & Memberikan umpan balik & 18,3 \\
\hline 9 & Membimbing siswa merangkum pelajaran & 8,3 \\
\hline No. & \multicolumn{2}{|c|}{ Aktivitas Siswa yang Diamati } \\
\hline 1 & $\begin{array}{l}\text { Mendengarkan/ memperhatikan penjelasan } \\
\text { guru }\end{array}$ & Persentase \\
\hline
\end{tabular}




\begin{tabular}{|l|l|c|}
\hline 2 & Membaca buku & 11,5 \\
\hline 3 & Bekerja dengan sesama anggota kelompok & 18,7 \\
\hline 4 & $\begin{array}{l}\text { Diskusi antar siswa/ antara siswa dengan } \\
\text { guru }\end{array}$ & 14,4 \\
\hline 5 & Menyajikan hasil pembelajaran & 2,9 \\
\hline 6 & Menyajikan/ menanggapi pertanyaan/ide & 5,2 \\
\hline 7 & Menulis yang relevan dengan KBM & 8,9 \\
\hline 8 & Merangkum pembelajaran & 6,9 \\
\hline 9 & Mengerjakan tes evaluasi & 8,9 \\
\hline
\end{tabular}

Berdasarkan tabel di atas tampak bahwa aktivitas guru yang paling dominan pada hasil siklus 1 adalah membimbing dan mengamati siswa dalam menemukan konsep, yaitu 21,7 \%. Aktivitas lain yang presentasinya cukup besar adalah memberi umpan balik/ evaluasi, tanya jawab dan menjelaskan materi yang sulit yaitu masing-masing sebesar 13,3\%. Sedangkan aktivitas siswa yang paling dominan adalah mengerjakan/ memperhatikan penjelasan guru yaitu 22,5\%. Aktivitas lain yang presentasinya cukup besar adalah bekerja dengan sesama anggota kelompok, diskusi antara siswa/ antara siswa dengan guru, dan membaca buku yaitu masing-masing 18,7 \% 14,4 dan $11,5 \%$.

Pada siklus 1, secara garis besar kegiatan belajar mengajar dengan model pembelajaran aptitude treatment interaction mampu meningkatkan keaktifan belajar siswa dalam pelaksanaan pembelajaran di kelas. walaupun peran guru masih cukup dominan untuk memberikan penjelasan dan arahan, karena model tersebut masih baru digunakan oleh guru maupun siswa. 
Tahap Refleksi

Pelaksanaan pembelajaran pada siklus 1 masih terdapat kekurangan sehingga perlu perbaikan untuk siklus selanjutnya. Agar kekurangan pada siklus pertama tidak terulang pada siklus selanjutnya, maka perlu perbaikan pada beberapa hal dalam pengelolaan pembelajaran yaitu, keterampilan guru dalam memotivasi siswa dalam belajar dalam rangka meningkatkan gairah dan aktivitas mereka dalam proses pembelajaran di kelas, guru juga harus mematangkan rencana pelaksanaan pembelajaran dengan alokasi yang tersedia sehingga rencana yang telah dibuat dapat berlangsung lebih maksimal.

\section{Siklus II}

Tahap Perencanaan

Pada tahap ini peneliti mempersiapkan perangkat pembelajaran yang terdiri dari rencana pelajaran 2, soal tes formatif 2 dan alat-alat pengajaran yang mendukung. Tahap Pelaksanaan

Pelaksanaan kegiatan belajar mengajar untuk siklus kedua dilaksanakan pada minggu pertama tanggal 2 Pebruari 2016 dengan jumlah siswa 46 siswa. Dalam hal ini peneliti bertindak sebagai guru. Adapun proses belajar mengajar mengacu pada rencana pelajaran dengan memperhatikan revisi pada hasil test siklus pertama, sehingga kesalahan atau kekurangan pada siklus pertama tidak terulang lagi pada siklus kedua. Pengamatan (observasi) dilaksanakan bersamaan dengan pelaksanaan pembelajaran. 
Djoni Hartono

Pada akhir proses belajar mengajar siswa diberi tes formatif kedua dengan tujuan untuk mengetahui tingkat keberhasilan siswa dalam proses belajar mengajar yang telah dilakukan. Instrumen yang digunakan adalah tes formatif kedua. Adapun data hasil penelitian pada siklus kedua adalah sebagai berikut:

Tabel 3: Pengelolaan Pembelajaran Pada Siklus 2

\begin{tabular}{|c|c|c|c|c|}
\hline \multirow{2}{*}{ No. } & \multirow{2}{*}{ Aspek yang Diamati } & \multicolumn{2}{|c|}{ Penilaian } & \multirow{2}{*}{$\begin{array}{l}\text { Rata- } \\
\text { rata }\end{array}$} \\
\hline & & $\mathrm{P} 1$ & $\mathrm{P} 2$ & \\
\hline \multirow{15}{*}{$\mathrm{I}$} & Pengamatan KBM & & & \\
\hline & Pendahuluan & & & \\
\hline & 1. Memotivasi Siswa & 3 & 3 & 3 \\
\hline & $\begin{array}{l}\text { 2. Menyampaikan tujuan } \\
\text { pembelajaran }\end{array}$ & 3 & 3 & 3 \\
\hline & $\begin{array}{l}\text { 3. Menghubungkan dengan } \\
\text { pelajaran sebelumnya }\end{array}$ & 3 & 3 & 3 \\
\hline & $\begin{array}{l}\text { 4. Mengatur siswa dalam } \\
\text { kelompok-kelompok } \\
\text { belajar }\end{array}$ & 3 & 3 & 3 \\
\hline & Kegiatan Inti & & & \\
\hline & $\begin{array}{l}\text { 1. Mempresentasikan } \\
\text { langkah-langkah metode } \\
\text { pembelajaran kooperatif }\end{array}$ & 4 & 4 & 4 \\
\hline & $\begin{array}{l}\text { 2. Membimbing siswa } \\
\text { melakukan kegiatan }\end{array}$ & 3 & 3 & 3 \\
\hline & $\begin{array}{l}\text { 3. Melatih keterampilan } \\
\text { kooperatif }\end{array}$ & 4 & 4 & 4 \\
\hline & $\begin{array}{l}\text { 4. Mengawasi setiap } \\
\text { kelompok secara bergiliran }\end{array}$ & 3 & 3 & 3 \\
\hline & $\begin{array}{l}\text { 5. Memberikan bantuan } \\
\text { kepada kelompok yang } \\
\text { mengalami kesulitan }\end{array}$ & 4 & 4 & 4 \\
\hline & Penutup & & & \\
\hline & $\begin{array}{l}\text { 1. Membimbing siswa } \\
\text { membuat rangkuman }\end{array}$ & 3 & 3 & 3 \\
\hline & 2. Memberikan evaluasi & 3 & 3 & 3 \\
\hline II & Pengelolaan Waktu & 3 & 3 & 3 \\
\hline
\end{tabular}




\begin{tabular}{|c|c|c|c|c|}
\hline \multirow{3}{*}{ III } & Antusiasme Kelas & & & \\
\hline & 1. Siswa & 4 & 4 & 4 \\
\hline & 2. Guru & 4 & 4 & 4 \\
\hline & Jumlah & 47 & 47 & 47 \\
\hline
\end{tabular}

Keterangan : Nilai : Kriteria

1) : Tidak Baik

2) : Kurang Baik

3) : Cukup Baik

4) : Baik

Dari tabel di atas, tampak aspek-aspek yang diamati pada kegiatan belajar mengajar pada siklus kedua yang dilaksanakan oleh guru dengan menerapkan model pembelajaran aptitude treatment interaction mendapatkan penilaian yang cukup baik. Maksudnya dari seluruh penilaian tidak terdapat nilai kurang. Namun demikian penilaian tesebut belum merupakan hasil yang optimal, untuk itu ada beberapa aspek yang perlu mendapatkan perhatian untuk penyempurnaan pada pembelajaran selanjutnya. Dengan penyempurnaan aspek-aspek siklus pertama dalam penerapan metode penggunaan model pembelajaran aptitude treatment interaction diharapkan siswa dapat menyimpulkan apa yang telah mereka pelajari dan mengemukakan pendapatnya sehingga mereka akan lebih memahami tentang apa yang telah mereka lakukan. Berikut ini tabel hasil observasi akivitas guru dan siswa:

Tabel 4: Aktivitas Guru dan Siswa Pada Siklus 2

\begin{tabular}{|c|l|c|}
\hline No. & \multicolumn{1}{|c|}{ Aktivitas Guru yang Diamati } & Persentase \\
\hline 1 & Menyampaikan tujuan & 6,7 \\
\hline 2 & Memotivasi siswa & 6,7 \\
\hline 3 & $\begin{array}{l}\text { Mengkaitkan dengan pelajaran } \\
\text { sebelumnya }\end{array}$ & 6,7 \\
\hline 4 & Menyampaikan materi/ langkah- & 11,7 \\
\hline
\end{tabular}




\begin{tabular}{|c|l|c|}
\hline & langkah/strategi & 11,7 \\
\hline 5 & Menjelaskan materi yang sulit & 25,0 \\
\hline 6 & $\begin{array}{l}\text { Membimbing dan mengamati siswa } \\
\text { dalam menemukan konsep }\end{array}$ & 8,2 \\
\hline 7 & $\begin{array}{l}\text { Meminta siswa menyajikan dan } \\
\text { mendiskusikan hasil kegiatan }\end{array}$ & 16,6 \\
\hline 8 & Memberikan umpan balik & 6,7 \\
\hline No. & $\begin{array}{l}\text { Membimbing siswa merangkum } \\
\text { pelajaran }\end{array}$ & Persentase \\
\hline 1 & $\begin{array}{l}\text { Mendengarkan/ Siswa yang Diamati } \\
\text { penjelasan guru }\end{array}$ & 17,9 \\
\hline 2 & Membaca buku & 12,1 \\
\hline 3 & $\begin{array}{l}\text { Bekerja dengan sesama anggota } \\
\text { kelompok }\end{array}$ & 21,0 \\
\hline 4 & $\begin{array}{l}\text { Diskusi antar siswa/ antara siswa } \\
\text { dengan guru }\end{array}$ & 13,8 \\
\hline 5 & Menyajikan hasil pembelajaran & 4,6 \\
\hline 6 & $\begin{array}{l}\text { Menyajikan/ menanggapi pertanyaan/ } \\
\text { ide }\end{array}$ & 5,4 \\
\hline 7 & Menulis yang relevan dengan KBM & 7,7 \\
\hline 8 & Merangkum pembelajaran & 6,7 \\
\hline 9 & Mengerjakan tes evaluasi & 10,8 \\
\hline
\end{tabular}

Berdasarkan tabel di atas, tampak bahwa aktifitas guru yang paling dominan pada siklus kedua adalah membimbing dan mengamati siswa dalam menentukan konsep yaitu 25\%.Jika dibandingkan dengan siklus I, aktivitas ini mengalami peningkatan. Aktivitas guru yang mengalami penurunan adalah memberi umpan balik/evaluasi/ Tanya jawab (16,6\%), mnjelaskan materi yang sulit $(11,7)$. Meminta siswa mendiskusikan dan menyajikan hasil kegiatan $(8,2 \%)$, dan membimbing siswa merangkum pelajaran $(6,7 \%)$.

Sedangkan untuk aktivitas siswa yang paling dominan pada siklus kedua adalah bekerja dengan sesama anggota 
kelompok yaitu (21\%). Jika dibandingkan dengan siklus pertama, aktifitas ini mengalami peningkatan. Aktifitas siswa yang mengalami penurunan adalah mendengarkan/memperhatikan penjelasan guru (17,9\%). Diskusi antar siswa/ antara siswa dengan guru (13,8\%), menulis yang relevan dengan KBM (7,7\%) dan merangkum pembelajaran (6,7\%). Adapun aktifitas siswa yang mengalami peningkatan adalah membaca buku $(12,1 \%)$, menyajikan hasil pembelajaran (4,6\%), menanggapi/mengajukan pertanyaan/ide $(5,4 \%)$, dan mengerjakan tes evaluasi $(10,8 \%)$.

Tahap Refleksi

Pada tahap ini, akan dikaji aspek-aspek yang telah terlaksana dengan baik maupun yang kurang baik pada pelaksanaan pembelajaran siklus kedua. Dari paparan data di atas, dapat diuraikan sebagai berikut: kekurangan pada siklus sebelumnya telah diperbaiki, meskipun ada beberapa aspek yang belum sempurna, tetapi persentase pelaksanaannya untuk masing-masing aspek mengalami peningkatan dan siswa juga lebih aktif dalam mengikuti pembelajaran di kelas.

\section{Siklus III}

Tahap Perencanaan

Pada tahap ini peneliti mempersiapkan perangkat pembelajaran yang terdiri dari rencana pelajaran 3 , soal tes formatif 3 dan alat-alat pengajaran yang mendukung. Tahap Pelaksanaan 
Pelaksanaan kegiatan belajar mengajar untuk siklus ketiga ini dilaksanakan pada minggu ketiga tangga 16 Pebruari 2016 dengan jumlah siswa 46 siswa. Dalam hal ini peneliti bertindak sebagai guru. Adapun proses belajar mengajar mengacu pada rencana pelajaran dengan memperhatikan revisi pada hasil test siklus kedua, sehingga kesalahan atau kekurangan pada siklus kedua tidak terulang lagi pada siklus kedua. Pengamatan (observasi) dilaksanakan bersamaan dengan pelaksanaan pembelajaran. Kemudian pada akhir proses belajar mengajar siswa diberi tes formatif ketiga dengan tujuan untuk mengetahui tingkat keberhasilan siswa dalam proses belajar mengajar yang telah dilakukan. Instrumen yang digunakan adalah tes formatif ketiga. Adapun data hasil penelitian pada siklus ketiga adalah sebagai berikut:

Tabel 5: Pengelolaan Pembelajaran Pada Siklus 3

\begin{tabular}{|c|c|c|c|c|}
\hline \multirow{2}{*}{ No. } & \multirow{2}{*}{ Aspek yang Diamati } & \multicolumn{2}{|c|}{ Penilaian } & \multirow{2}{*}{$\begin{array}{c}\text { Rata- } \\
\text { rata }\end{array}$} \\
\hline & & $\mathrm{P} 1$ & P2 & \\
\hline \multirow{9}{*}{ I } & Pengamatan KBM & & & \\
\hline & Pendahuluan & & & \\
\hline & 1. Memotivasi Siswa & 4 & 4 & 4 \\
\hline & $\begin{array}{l}\text { 2. Menyampaikan tujuan } \\
\text { pembelajaran }\end{array}$ & 4 & 4 & 4 \\
\hline & $\begin{array}{l}\text { 3. Menghubungkan dengan } \\
\text { pelajaran sebelumnya }\end{array}$ & 3 & 3 & 3 \\
\hline & $\begin{array}{l}\text { 4. Mengatur siswa dalam } \\
\text { kelompok-kelompok } \\
\text { belajar }\end{array}$ & 4 & 4 & 4 \\
\hline & Kegiatan Inti & & & \\
\hline & $\begin{array}{l}\text { 1. Mempresentasikan } \\
\text { langkah-langkah metode } \\
\text { pembelajaran kooperatif }\end{array}$ & 4 & 4 & 4 \\
\hline & $\begin{array}{l}\text { 2. Membimbing } \\
\text { melakukan kegiatan }\end{array}$ & 3 & 3 & 3 \\
\hline
\end{tabular}


Efektifitas Model Pembelajaran

\begin{tabular}{|c|c|c|c|c|}
\hline & 3. Melatih keterampilan & 4 & 4 & 4 \\
\hline & $\begin{array}{l}\text { 4. Mengawasi } \\
\text { kelompok secara bergiliap }\end{array}$ & 3 & 3 & 3 \\
\hline & $\begin{array}{l}\text { 5. Memberikan bantuan } \\
\text { kepada kelompok yang } \\
\text { mengalami kesulitan }\end{array}$ & 4 & 4 & 4 \\
\hline & Penutup & & & \\
\hline & $\begin{array}{l}\text { 1. Membimbing siswa } \\
\text { membuat rangkuman }\end{array}$ & 4 & 4 & 4 \\
\hline & 2. Memberikan evaluasi & 3 & 3 & 3 \\
\hline II & Pengelolaan Waktu & 4 & 4 & 4 \\
\hline \multirow{4}{*}{ III } & Antusiasme Kelas & & & \\
\hline & 1. Siswa & 4 & 4 & 4 \\
\hline & 2. Guru & 4 & 4 & 4 \\
\hline & Jumlah & 52 & 52 & 52 \\
\hline
\end{tabular}

Keterangan : Nilai : Kriteria

1) : Tidak Baik

2) : Kurang Baik

3) : Cukup Baik

4) : Baik

Dari tabel di atas, dapat dilihat aspek-aspek yang diamati pada kegiatan belajar mengajar pada siklus ketiga yang dilaksanakan oleh guru dengan menerapkan model pembelajaran aptitude treatment interaction mendapatkan penilaian yang baik, terutama pada aspek memotivasi siswa, membimbing siswa merumuskan kesimpulan/menemukan konsep, dan pengelolaan waktu. Berikut ini tabel hasil observasi akivitas guru dan siswa pada siklus ketiga:

Tabel 6: Aktivitas Guru dan Siswa Pada Siklus 3

\begin{tabular}{|c|l|c|}
\hline No. & \multicolumn{1}{|c|}{ Aktivitas Guru yang Diamati } & Persentase \\
\hline 1 & Menyampaikan tujuan & 6,7 \\
\hline 2 & Memotivasi siswa & 6,7 \\
\hline 3 & $\begin{array}{l}\text { Mengkaitkan dengan pelajaran } \\
\text { sebelumnya }\end{array}$ & 10,7 \\
\hline
\end{tabular}




\begin{tabular}{|c|l|c|}
\hline 4 & $\begin{array}{l}\text { Menyampaikan materi/ langkah- } \\
\text { langkah/ strategi }\end{array}$ & 13,3 \\
\hline 5 & Menjelaskan materi yang sulit & 10,0 \\
\hline 6 & $\begin{array}{l}\text { Membimbing dan mengamati siswa } \\
\text { dalam menemukan konsep }\end{array}$ & 22,6 \\
\hline 7 & $\begin{array}{l}\text { Meminta siswa menyajikan dan } \\
\text { mendiskusikan hasil kegiatan }\end{array}$ & 10,0 \\
\hline 8 & Memberikan umpan balik & 11,7 \\
\hline 9 & $\begin{array}{l}\text { Membimbing siswa merangkum } \\
\text { pelajaran }\end{array}$ & 10,0 \\
\hline No. & \multicolumn{1}{|c|}{ Aktivitas Siswa yang Diamati } & 20,8 \\
\hline 1 & $\begin{array}{l}\text { Mendengarkan/ } \\
\text { penjelasan guru }\end{array}$ & 13,1 \\
\hline 2 & Membaca buku & 22,1 \\
\hline 3 & $\begin{array}{l}\text { Bekerja dengan sesama anggota } \\
\text { kelompok }\end{array}$ & 15,0 \\
\hline 4 & $\begin{array}{l}\text { Diskusi antar siswa/ antara siswa dengan } \\
\text { guru }\end{array}$ & 2,9 \\
\hline 5 & Menyajikan hasil pembelajaran & 4,2 \\
\hline 6 & $\begin{array}{l}\text { Menyajikan/ menanggapi pertanyaan/ } \\
\text { ide }\end{array}$ & 6,1 \\
\hline 7 & Menulis yang relevan dengan KBM & 7,3 \\
\hline 8 & Merangkum pembelajaran & 8,5 \\
\hline 9 & Mengerjakan tes evaluasi & \\
\hline & Berdasarkan tabel d atas tampak bahwa aktivas \\
\hline
\end{tabular}

Berdasarkan tabel di atas tampak bahwa aktivitas guru yang paling dominan pada siklus ketiga adalah membimbing dan mengamati siswa dalam menemukan konsep yaitu $22,6 \%$. Sedangkan aktivitas menjelaskan materi yang sulit dan memberi umpan balik/evaluasi/tanya jawab menurun masing-masing sebesar (10\%), dan (11,7\%). Aktivitas lain yang mengalami peningkatan adalah mengkaitkan dengan pelajaran sebelumnya (10\%), menyampaikan materi/strategi/langkah-langkah (13,3\%), meminta siswa menyajikan dan mendiskusikan hasil kegiatan 
(10\%), dan membimbing siswa merangkum pelajaran (10\%). Adapun aktivitas yang tidak mengalami perubahan adalah menyampaikan tujuan $(6,7 \%)$ dan memotivasi siswa $(6,7 \%)$.

Sedangkan untuk aktivitas siswa yang paling dominan pada siklus ketiga adalah bekerja dengan sesama anggota kelompok yaitu $(22,1 \%)$ dan mendengarkan/memperhatikan penjelasan guru (20,8\%), aktivitas yang mengalami peningkatan adalah membaca buku $(13,1 \%)$ dan diskusi antar siswa/antara siswa dengan guru $(15,0 \%)$. Sedangkan aktivitas yang lainnya mengalami penurunan.

Tahap Refleksi

Pada tahap ini akan dikaji apa yang telah terlaksana dengan baik maupun yang masih kurang baik dalam proses belajar mengajar dengan penerapan model pembelajaran aptitude treatment interaction. Dari data-data yang telah diperoleh dapat duraikan sebagai berikut: Kekurangan pada siklus-siklus sebelumnya sudah mengalami perbaikan dan peningkatan sehingga menjadi lebih baik. Aktivitas siswa dalam mengikuti kegiatan belajar di kelas juga semakin meningkat dan bersemangat. Selanjutnya yang perlu diperhatikan adalah memaksimalkan dan mempertahankan apa yang telah ada agar pada pelaksanaan proses belajar mengajar berikutnya penerapan model pembelajaranaptitude treatment interaction benar-benar mampu meningkatkan aktivitas siswa dalam belajar karena keaktifan siswa bisa dijadikan salah satu faktor keberhasilan 
belajar mereka sehingga tujuan pembelajaran yang telah ditentukan dapat tercapai secara lebih maksimal.

Berdasarkan uraian dari ketiga siklus di atas, dapat diambil pemahaman bahwa sejak siklus pertama guru telah menerapkan model pembelajaran Aptitude Treatment Interaction (ATI) dengan cukup baik dan berlangsung sesuai alokasi waktu yang telah ditetapkan dalam rencana pelaksanaan pembelajaran. Penerapan model pembelajaran tersebut terus dilaksanakan hingga siklus ketiga. Pada setiap siklus menuju siklus selanjutnya terdapat peningkatan aktivitas belajar siswa. Dengan adanya aktivitas belajar siswa yang semakin meningkat, maka penerapan model tersebut pada akhirnya akan mampu menopang prestasi belajar siswa karena aktivitas siswa merupakan salah satu indikasi yang dapat mengantarkan siswa untuk mencapai keberhasilan belajarnya. Adapun aktivitas siswa yang paling menonjol dengan penerapan model ATI adalah kerjasama kelompok, diskusi (baik antar siswa maupun antara siswa dengan guru). Selain itu, aktivitas guru juga mengalami beberapa penyesuaian dalam rangka meningkatkan aktivitas siswa dengan model tersebut. Aktivitas guru yang muncul lebih dominan adalah aktivitas membimbing dan mengamati kegiatan belajar siswa, menjelaskan, dan memberi umpan balik.

\section{Penutup}

Model pembelajaran aptitude treatment interaction sangat bermanfaat bagi siswa karena model pembelajaran ini mampu 
menampung perbedaan individual masing-masing siswa. Selain itu, model ini juga membuat interaksi edukatif antara sesama siswa maupun siswa dengan guru menjadi lebih interaktif. Dengan interaksi yang demikian itu, siswa menjadi lebih leluasa dan percaya diri untuk mengungkapkan pendapatnya dalam proses pelaksanaan pembelajarn di kelas. Dengan demikian, partisipasi siswa dalam mengikuti kegiatan pembelajaran di kelas menjadi lebih aktif. Keaktifan siswa dalam kegiatan pembelajaran di kelas merupakan salah satu indikator positif yang nantinya akan berdampak pada keberhasilan belajarnya.

\section{Daftar Rujukan}

A.M, Sardiman . Interaksi dan Motivasi Belajar Mengajar. Jakarta: RajaGrafindo Persada, 2014.

Arikunto, Suharsimi. Penelitian Tindakan Kelas. Jakarta: Bumi Aksara, 2010.

Danim, Sudarwan. Perkembangan Peserta Didik. Bandung: Alfabeta, 2010.

Daryanto. Evaluasi Pendidikan. Jakarta: Rineka Cipta, 2012.

Djamarah, Syaiful Bahri. Guru dan Anak Didik dalam Interaksi Edukatif. Jakarta: Rineka Cipta, 2005.

Djamarah, Syaiful Bahri dan Aswan Zein. Strategi Belajar Mengajar. Jakarta: Rineka Cipta, 2013.

Dongoran, Zulkipli. "Efek Model Pembelajaran ATI (Aptitude Treatment Interaction) terhadap Aktivitas dan Generik Sains Fisika Siswa", Jurnal Pendidikan Fisika, Vol. 3 No. 2, 2014. 
Djoni Hartono

Huda, Miftahul. Model-model Pengajaran dan Pembelajaran: Isu-isu Metodis dan Pragmatis. Yogyakarta: Pustaka Pelajar, 2014.

Joyce, Bruce, Marsha Weil, dan Emily Calhoun. Models of Teaching: Model-model Pengajaran. terj. Achmad Fawaid dan Ateilla Mirza. Yogyakarta: Pustaka Pelajar, 2011.

Madani, Warta. "Konsep Pembelajaran ATI (Aptitude Treatment Interaction)", dalam http://jenteranews.blogspot.com/2013/05/konseppembelajaran-ati-aptitude.html

Sudrajat, Akhmad . "Pengertian Pendekatan, Strategi, Metode, Teknik, Taktik dan Model Pembelajaran", https://akhmadsudrajat.wordpress.com/2008/09/12/p endekatan-strategi-metode-teknik-dan-modelpembelajaran/

Sunarto dan Agung Hartono. Perkembangan Peserta Didik. Jakarta: Rineka Cipta, 2008. 